Amalia Ran

\title{
Jewish Latin American Literary Studies: Between Old Challenges and New Paradigms
}

The growing interest in Jewish Latin American literature in recent decades led researchers and academic institutions to focus on the multiple expressions of Jewish identity and Jewishness in the hemisphere, on immigration, dislocation, and personal and collective affiliations, while often emphasizing the numerous conjunctions between history and the narrative act, as indicated in the large number of scholarly works and of courses on the subject. ${ }^{1}$

At the same time, particularly since the turn of the twenty-first century, emerges the demand to revise old paradigms in order to face new political, socio-economic, cultural and epistemological challenges in Latin America, within the Jewish world, and around the globe. In this framework, I seek to explore new pathways for researching and studying Jewish Latin American literature by reviewing the challenges with which we face at present in our profession and by suggesting alternative strategies for teaching and learning the subject.

The academic world underwent significant transformations related to the digital revolution, the changing nature of learning, and the omnipresence of knowledge and increasing number of data of various forms (Daniel, 2015; Scheffel et al., 2014; Pardo and Siemens, 2014; Becker et al., 2017). In the Humanities, the declining number of students and shrinking resources produced a new crisis, visible also in departments of Jewish studies around the world. How do these predicaments affect Jewish literary studies? Which academic practices should be promoted in order to face the decline in the number of students in courses such as Judeo-Latin American fiction or Sephardic literature, for example? Moreover, as technology and digital pedagogy reshape our field and set new norms for teaching and learning, our concerns relate also to methodological and theoretical aspects: Is it still possible to conduct a pure aesthetic relationship with the literary text in a world infiltrated by digital hypertexts and instant messages? In the following pages, I wish to highlight several challenges which we face today as scholars of Jewish literary studies. I should stress that these challenges are not unique to our field; yet, by confronting them, we may envision new para-

1 See for example the list of syllabi at LAJSA website: http://www.lajsa.org/resources/syllabiand-course-descriptions/ (24 September 2019).

Ә OpenAccess. () 2020 Amalia Ran, published by De Gruyter. (cc) BY-NC-ND This work is licensed under the Creative Commons Attribution-NonCommercial-NoDerivatives 4.0 License. 
digms for teaching, researching and learning Jewish literature on its various hemispheric expressions.

\section{Challenge I: Decline in the Number of Students}

In his 2015 survey for the AJS (American Jewish Studies Association), Michael Cohen (2015) underlined the retraction in tenure-track job opportunities in the field of Jewish studies, in public and private funding, and in course enrollments due to the financial crisis of 2008 in the United States, which presented new challenges for Jewish Studies, as well as for other academic fields in the Humanities, the arts and in sciences. Cohen reported the correlation between the decline in student enrollment and between the dwindling job market for new professors of literature and of other humanistic subjects. Nonetheless, his survey still found that amongst the most widely taught subjects were courses on Jewish literature (20\%). Approximately $13 \%$ of the respondents in Cohen's survey specialized in modern Jewish history in Europe/Asia/Israel/ and other communities; only 1.8\% of the participants in this survey reported being employed in Departments of Romance Languages, and 2.3\% in Department of Comparative Literature (Cohen, 2015).

A census on behalf of the Modern Languages Association (MLA), which was conducted in 2013, supported these findings by reporting that overall enrollments of students in literary studies and linguistics in the United States were falling by $6.7 \%$ from the previous year. The MLA census did not specify whether the drop represented an anomaly in the growth of enrollments that had continued uninterrupted since 1998 or was the beginning of a sustained downward trend; something that had not happened since the 1970s. However, as indicated three years afterwards by the 2016 MLA census, enrollments in languages other than English fell in 9.2\% in colleges and universities around the United States; thus, confirming a global trend in the Humanities (Looney and Lusin, 2018). In Israel, a similar process is reported as well. Most recently, Professor Eyal Ziser, Vice Rector of Tel Aviv University, emphasized the decline in the number of students in the Humanities in a panel on innovation and technology in institutions of higher education (2018): only 8-9\% of the students choose to study a degree in the Humanities, claiming that it is unpractical, too academic, and does not prepare them for the job market. Nonetheless, insisted Ziser, leaders in the financial and business sectors are still seeking employees who are not only technocrats (with degrees for instance in computer sciences and engineering alone) but who have wide knowledge and critical skills attained by completing programs in humanistic disciplines. 
Overall, the decline in student enrollment characterizes most of the fields in the Humanities, including Jewish studies and literary studies, and any future proposal for increasing student enrollments in these fields should address the question of how to appeal to new candidates, how to become relevant again for students at the twenty-first century, and how to use innovative technology and new learning pedagogies in order to attract future scholars into the research of Jewish literary studies on its multiple regional expressions.

\section{Challenge II: Traditional Disciplinary Divisions}

Academic institutions were and still are traditionally divided into spheres of knowledge based upon an imagined disciplinary line, resisting the growing demands for emphasis on interdisciplinary and multi-disciplinary connectivity and collaborations in the academia and beyond its walls. I should note that in a sense Jewish studies have always defied this rigid structure, since the field encompassed multiple scholarly disciplines (history, literature, languages, and religion among others). Within the particular sub-field of Jewish Latin American literary studies, its multiple roots in Latin American studies, in Jewish studies, as well as in literary studies, obfuscated any attempt for clear, hermetic, disciplinary categorization, which eventually led also to the creation of two independent academic associations as professional frameworks dedicated specifically to the subject.

AMILAT (Asociación Israelí de Investigadores del Judaísmo Latinoamericano) and LAJSA (Latin American Jewish Studies Association) were created exactly because of these multi-disciplinary affinities: Both organizations sought to constitute local scholarly communities to debate theoretical and practical concerns within the field of Jewish Latin America and beyond its multiple disciplinary borders. In a sense, both organizations, created in the late 1970s and 1980s respectively, deliberately or not, created a hybrid field of studies comprising scholars from different research fields, various hemispheres (Latin America, North America, Israel and Europe), and languages (English, Spanish, Portuguese, Hebrew, Yiddish and Ladino) who happened to share their expertise, including in philology and literary studies (Laikin Elkin, 2016).

At present, the need to revise traditional disciplinary structures is as urgent as ever before; what should we learn from the example of Jewish Latin American literary studies? Courses on Jewish Latin American fiction appeal to a wide audience of students from literary studies, Jewish studies, Spanish and Latin American literature, ethnic studies, and diasporic studies; should we use this sub- 
field as a model for successful hybrid and multi-disciplinary scholarly environment for promoting Jewish literary studies?

\section{Challenge III: Teaching and Learning Jewish Latin American Literature and "Generation Z" Students}

Most of our current students are "Generation Z" representatives also known as “iGeneration” natives (Montana and Petit 2008; Rosen 2011). This fact demands a shift in our teaching methodologies and in how we facilitate students' access to knowledge in our field. Much has been said about our current audience of learners: their alleged incapability of expressing themselves orally and by writing; their difficulties of analyzing a text into depth; their attention deficits and the effect of these shortages on learning; Moreover, their access to unlimited amount of data and information through the Web challenges professors' traditional role as single sources of knowledge. This generation of students is much more exposed to knowledge than their precursors (and much more globally oriented and open to embrace new trends and paradigms, I should add). It seems that in face of these circumstances, our third challenge is also our most urgent one: How to teach these students? How to enhance their knowledge and get them involved and interested in our field? In short, how to make Jewish literary studies relevant again for this new generation of students?

\subsection{Old and New Paradigms}

According to the NMC Horizon Report: 2017 Higher Education Edition in Teaching and Learning (Becker et al., 2017), to implement change in the academia implies endorsing a cultural transformation by:

1. Promoting the exchange of fresh ideas and advancing progressive learning approaches;

2. Relating to real-world skills in view of future employability;

3. Creating collaborations with learning communities and multidisciplinary approaches;

4. Shifting to digital humanities (for example, by using Blogs to foster deeper student learning, or by using blended learning designs such as a combination of traditional, face-to-face teaching with modes of technology-facilitat- 
ed instruction like the flipped-classroom model, rearranging time spent in the classroom to promote more active learning and collaboration);

5. Promoting authentic and ubiquitous learning.

Consequently, it appears that a redefinition of the relationship between learners, knowledge and faculty is required. Instead of thinking of knowledge as something static, which passes from professors to students, knowledge should be perceived as something fluent, that is constantly created and revised; at the same time, as radical as it may sound, we ought to recognize our students' ability to contribute to the body of knowledge in our field by reconstructing our pedagogical and theoretical concepts of teaching and learning (DeRosa and Robinson, 2017). Yet, how should we implement these drastic changes in Jewish literary studies?

In the field of Jewish Latin American literature, we need to break free from discussing Jewish experience as an a priori, exceptional category of analysis, which ignores factors such as generational gaps, similar experiences of dislocation and marginality experienced by other minority groups in Latin America, the diminishing place Zionism and Israel occupies in the lives of Jews around the world at present, or the role of diaspora as a defining element in migrant identities. These new considerations should guide our way upon instigating a new curriculum.

Within the realm of Jewish Latin American literary studies, one should wonder how to classify new works published by Jewish Latin American authors who currently reside in Europe, Israel or in the United States such as Eduardo Halfon - a Jewish Guatemalan author who grew up in the United States - or the Jewish Argentine writer Eduardo Lázaro Covadlo who lives in Spain. Their works force us to rethink of old academic paradigms and consider new polemic proposals raised by the public of readers, by the academic and editorial world, and by the literary text itself, as they represent a unrooted, transnational and multilingual echoes that transcend their Jewishness and hemispheric affiliations. At the same time, as emphasized by a number of scholars in recent years, the exceptionality of Jewish protagonists as minor, marginal and excluded entities in many local contexts (for example: in Argentina, Mexico, Brazil) disappears in favor of new representations of urban, middle-class (often masculine) prototypes who accidently (or not) happen to be Jewish as well. They no longer represent only the marginal character who suffers from the "double-identity" crises due to dual loyalties and affiliations. Instead, they "float" between various imaginary and tangible territories without any apologetic tone or unique characteristics that single them out. Hence, these new considerations ought to be taken into account once remodeling the curriculum of Jewish Latin American literary studies. 
Perhaps it is also the adequate moment to employ a new "academic language" and to constitute another kind of relationship with students and scholars in order to enhance Jewish literary studies. The field of Jewish studies originated from the millenary tradition of reading and interpreting the Book. Jewish literary studies in particular nourished from the polemic tradition of the sages and the Kabbalistic prism of multilayer inferences. However, this tradition is losing its primacy in Jewish literary studies at the digital era. By rethinking our relationship with the literary text, with our students and with the profession itself we may reach a new form for communicating and transferring knowledge. Following Roman Jacobson's model of communication (1960), this alternative "academic" language should offer a new channel for transmitting messages and discussing them while embracing new types of senders and receivers; and while accepting the changing contextual framework, as well as the channel of transmission and the codes.

The following example may illustrate in which way the adoption of new communication channels in our field led to the improvement of students' outcomes and involvement in the subject matter, by implementing an innovative curriculum and including the students in the research of the field: In his course entitled "Murder, Madness and Mayhem: Latin American Literature in Translation,” Jon Beasley-Murray, a professor from the University of British Columbia in Canada, decided to incorporate an assignment that replaced a more traditional research paper, which was based on an initiative on behalf of the Wiki Education Foundation. He requested from his students to write or improve a Wikipedia article on Latin American literature. According to Beasley-Murray, this task consisted of "teaching the students research skills and writing skills in what [was] very much a real world environment.” (De Rosa and Robinson 2017, 119). Hence, throughout the semester, the students researched in groups, wrote and edited an article, which was later evaluated not only by their classmates and by the professor, but also by the public of readers on the digital domain. Consequently, the amount of articles on Wikipedia that focused on Latin American literature increased, and although the question of their scholarly quality remains open, the public evaluation mechanism enabled their improvement and positive rating over time. This example demonstrates how by using alternative learning and teaching modes, Beasley-Murray engaged his students in research, triggering their curiosity and interest in the course, and conduced them to deepen their knowledge in the field.

Alternative channels of communication may be established also by incorporating Open Education Resources in the curriculum. Beyond their financial and social benefits for students, Open Education Resources could be critical essays, narrative texts, textbooks, video conferences, or any other educational material 
that are free of use (under certain limitations of privacy and copyrights) for academic purposes. This way, a tentative course on Jewish Latin American literature based upon OER may incorporate Halfon's ${ }^{2}$ and Covadlo's ${ }^{3}$ blogs for example. Both Jewish authors, mentioned previously, publish some of their stories online (as well as press interviews, personal statements and short biographies). Why not incorporating these narrative texts into the classroom? Students may also share their analysis and commentaries on the narrative text on a digital class blog. The literary text still reigns at the center of our attention but the methodological and pedagogical pathways to analyze and study it reflect an alternative attitude for learning, teaching and researching, referred previously as a new "academic language."

Lastly, certain traditional Jewish themes such as the wandering experience, migration, life in translation, solitude and alienation appear to be universal concerns at the twenty-first century. We no longer speak in terms of one single history to narrate, one single nationality, or a single identity to define oneself; many literary works emphasize this change at present. Hence, we should reflect it also in our profession: By addressing the needs of our new audience of learners, by thinking of alternative teaching and learning venues, and by fostering new themes and literary representations, and alternative research and pedagogical methodologies.

\section{Bibliography}

Becker, Samantha Adams, M. Cummins, A. Davis, A. Freeman, C. Glesinger Hall, and V. Ananthanarayanan. NMC Horizon Report: 2017 Higher Education Edition. Austin, Texas: The New Media Consortium, 2017.

Cohen, Steven M. Profiling the Jewish Studies Profession in North America Highlights form the Survey of AJS Members. The 2015 Association for Jewish Studies Membership Survey, 2015.

Daniel, Ben. "Big Data and analytics in higher education: Opportunities and challenges." British Journal of Educational Technology 46.5 (2015): 904-920.

DeRosa, Robin, and Scott Robison. "From OER to Open Pedagogy: Harnessing the Power of Open." In Open: The Philosophy and Practices that are Revolutionizing Education and Science, edited by Rojiv Jhangiani, and Robert Biswas-Diener, 115-124. London: Ubiquity Press, 2017. Retrieved from: DOI: https://doi.org/10.5334/bbc.i. License: CC-BY 4.0.

Jacobson, Roman. "Linguistics and Poetics." Style in Language. Ed. T. Sebeok, 350-377. Cambridge, MA: M.I.T. Press, 1960.

2 https://www.wordswithoutborders.org/article/white-sand-black-stone (24 September 2019).

3 http://www.covadlo.com/textos/textos.htm (24 September 2019). 
Laikin Elkin, Judith. The Origins of the Latin American Jewish Studies Association: 1982-1995. Ann Arbor, MI: 2016.

Looney, Dennis, and Natalia Lusin. Enrollments in Languages Other Than English in United States Institutions of Higher Education, Summer 2016 and Fall 2016: Preliminary Report Web publication, 2018. Retrieved from: https://www.mla.org/content/download/83540/ 2197676/2016-Enrollments-Short-Report.pdf

Montana, Patrick, and Francis Petit. "Motivating Generation $\mathrm{X}$ and $\mathrm{Y}$ on the Job and Preparing Z." Global Journal of Business Research 2.2 (2008): 139-148.

Pardo, Abelardo, and George Siemens. "Ethical and Privacy Principles for Learning Analytics." British Journal of Educational Technology 45.3 (2014): 438-450.

Rosen, Larry, D. "Teaching the iGeneration." Educational Leadership: Journal of the Department of Supervision and Curriculum Development 68.5 (2011): 10-15.

Scheffel, Maren, Hendrik Drachsler, Slavi Stoyanov, and Marcus Specht. "Quality Indicators for Learning Analytics.” Educational Technology \& Society, 17.4 (2014): 117-132.

Ziser, Eyal. "Presentation at Teldan Conference.” Tel Aviv, 14 May, 2018. 